\title{
EGÉSZSÉGÜGYI KOCKÁZATOT JELENTŐ VEGYI ANYAGOK, AMELYEK TÁPLÁLKOZÁSUNK SORÁN A SZERVEZETÜNKBE KERÜLHETNEK
}

DOI: $10.30583 / 2018 / 1-2 / 79$

\author{
„A jó minőségü élelmiszer \\ nem más, mint olcsó \\ egészségbiztosítás". \\ Scott Jurek
}

\section{Absztrakt:}

A technika rohamos fejlődésével, a globalizációval, urbanizációval az ember természetes környezetét egyre inkább mesterséges környezetté alakitja át. Környezetünkböl is és a tápláléklánc útján is egyre több testidegen anyag kerül szervezetünkbe. Az orvostudomány fejödése ellenére rohamosan nő a különböző allergiás megbetegedésekben, emésztörendszeri, anyagcsere, daganatos, valamint szív- és érrendszeri betegségben szenvedők száma. A cikk a teljesség igénye nélkül mutatja be az egészségünket veszélyeztető vegyi anyagokat, valamint az élelmiszer-biztonságot a XXI. században befolyásoló tényezőket. Ha minden embernek biztosítani tudnánk a megfelelő mennyiségü és minőségü táplálékot és testmozgást - nem túl keveset, nem túl sokat -, akkor megtalálnánk a legbiztosabb utat az egészséghez.

Kulcsszavak: élelmiszer-biztonságot befolyásoló tényezők, vegyi anyagok, egészség, minőség, biztonság,

\section{Abstract:}

With the advance of technology, globalization and urbanization humans are gradually turning their natural environment into an artificial one. More and more foreign substances from the environment as well as via the food chain are finding their way into our bodies. Despite the advances in medical science, the incidence rate of allergic, gastroin-

1 Dr. Horváth Lívia Katonai Müszaki Doktori Iskola PhD hallgató.

ORCID: 0000-0002-8213-3936 
testinal, metabolic, tumorous and cardiovascular diseases is growing rapidly. This article offers a non-exhaustive overview of the toxic components found in our nutrition and the factors influencing food safety in the $21^{\text {st }}$ century. If we could provide the right amount and quality of food and exercise to our bodies - not too much or too little then we were on the safest way to good health.

Keywords: Chemicals in our nutrition, their dietary intake and health risks

\section{Bevezetés}

Mindennapi életünkben az élelmiszereknek és az étkezésnek kiemelten fontos szerepe van. Ezt igazolja, hogy az Európai Bizottság által támogatott, „Életminőség és az élő erőforrások kezelése” címü európai együttmúködési program köré rendeződtek az elmúlt évek folyamán az európai élelmiszer-tudományi, táplálkozás-tudományi és élelmiszer-technológiai kutatások. Ezt Peter Belton, angolszász szerző úgy fejezi ki [1], hogy „az élelmiszer nem tárgy, hanem kölcsönhatás", azaz bizonyos biológiai anyagok akkor válnak élelmiszerré, ha emberi étvágyat elégítenek ki.

Élelmiszernek nevezünk minden olyan terméket, anyagot, amelyek feldolgozott, részben feldolgozott vagy feldolgozatlan formában kerülnek emberi fogyasztásra. Az élelmiszerek közé tartozik az élelmiszerekben előforduló víz is, továbbá azok az anyagok, amelyeket az előállitás, feldolgozás, illetve kezelés során szándékosan a termékhez adnak [2].

Az élelmiszerek származása szerint megkülönböztetünk ásványi, növényi és állati eredetủeket, feldolgozottság alapján lehetnek nyers, feldolgozatlan vagy feldolgozott élelmiszerek, élettani hatásuk szerint csoportosíthatjuk alaptápanyagokra (fehérje, zsír, szénhidrát) és védőtápanyagokra (vitaminok, ásványi anyagok) [3]. Az élelmiszerek nélkülözhetetlenek az emberi életben, táplálkozással kerülnek a szervezetünkbe.

Ismert tény, hogy az életmódbeli tényezők, mozgás, táplálkozás szerepet játszanak mind a születéskor várható hosszabb élettartam 
alakulásában, mind pedig a különböző megbetegedések megelőzésében.

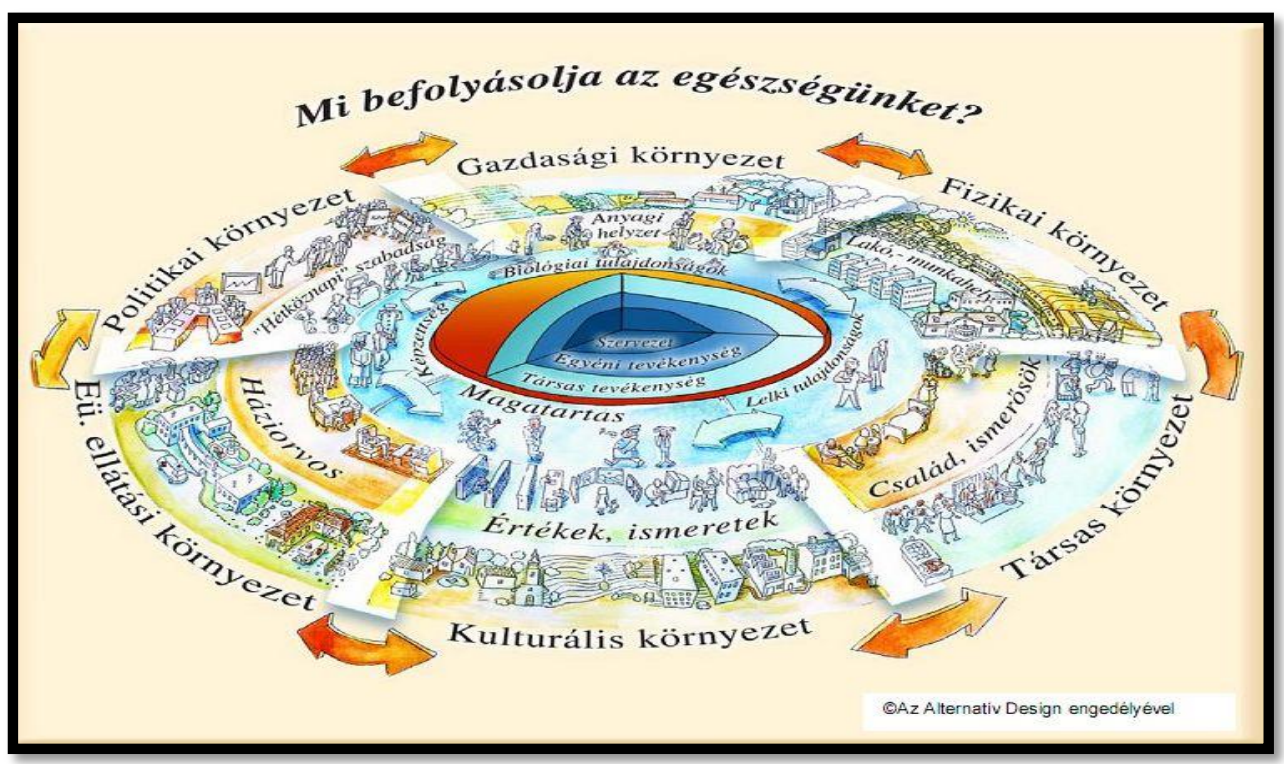

1. számú ábra. Egészségünket befolyásoló tényezők

A kérdés komplex, és sok itthon a tennivaló e téren. Ezt támasztja alá, hogy a 2016-ban publikált eredmények alapján az EU összes tagállamában a születéskor várható átlagos élettartam 81 év, míg Magyarországon ez csak 76 év. Különbség van a nemek tekintetében is: a férfiak hazánkban alig több mint 72 évre számíthatnak, míg egy átlagos uniós állampolgár 78 évre. A nők esetében 79 és fél év a várható élettartam, ami négy évvel kevesebb, mint az uniós átlag.

Ebben a cikkemben én részletesen a táplálkozással kívánok foglalkozni a továbbiakban.

A téma mindenkori aktualitását igazolja, hogy a táplálkozással elfogyasztott különböző élelmiszerek, illetve az élelmiszerek komponensei, az élelmiszerek mennyisége és minősége az egészség védelmében, vagy akár megbetegedések kialakulásában komoly szerepet játszhatnak. Az egészség védelmét szolgáló élelmiszerek között szerepelnek a probiotikumokat és prebiotikumokat ${ }^{3}$ tartalmazó funk-

2 Olyan készítmények (táplálék-kiegészítők, gyógyszerek), amelyek az emberi szervezet számára jótékony baktériumokat, Bifidobaktérium és Lactobacillus törzseket tartalmaznak.

3 Prebiotikumok: a jótékony baktériumok, azaz a probiotikumok szaporodását segítik a bélrendszerben. 
cionális élelmiszerek, az összetett szénhidrátokat tartalmazó gabonafélék és az egyes zöldségekben és gyümölcsökben lévő természetes antioxidánsok is [5]. Az élelmiszerekkel szemben a legfontosabb elvárás, hogy az év minden szakaszában megfelelő mennyiségben és minőségben álljanak rendelkezésre, legyenek emberi fogyasztásra alkalmasak, és semmilyen módon ne veszélyeztessék a fogyasztó egészségét [2]. Táplálkozásunk során tehát az élelmiszerek minőségének is fontos szerepe van. A XXI. században a fejlett országok társadalmának - beleértve a haderőt is - nő az igénye a megfelelő minőségü élelmiszerek iránt, és egyre inkább érdeklik az élelmiszerek származása, összetétele, fogyaszthatóságának feltételei. Az élelmiszer-biztonság fontos része az élelmiszer-minőség, amely éppen ezért külön figyelmet érdemel az élelmezési láncban. Élelmiszerbiztonságon az élelmiszer azon tulajdonságainak összességét értjük, amelyek alkalmassá teszik a rá vonatkozó előírásokban rögzített és a fogyasztók által elvárt igények kielégítését. Az élelmiszerekbe, ha nem valósul meg a mikrobiológiai kémiai biztonság, különböző egészségre ártalmas mikroorganizmusok (pl. Szalmonella) kerülhetnek be vagy szaporodhatnak el [2].

A lakosság jó minőségű és megfelelő mennyiségű élelmiszerrel való ellátása állami feladat. Olyan termékek előállítására van szükség, amelyek biztosítják a lakosság fejlődését, egészségének fenntartását. $A$ kémiai élelmiszer-biztonság szolgál arra, hogy a fogyasztó szervezetébe az élelmiszerek és az ivóvíz közvetítésével meghatározott megengedhető/tolerálható napi/heti bevitelt meghaladó mennyiségü adalék-, illetve szennyezőanyag ne kerülhessen. A biztonság a toxikológiai kísérletek eredményeit és egyéb biológiai szempontokat veszi figyelembe a határérték meghatározásánál. A mg/ttkg/nap egységben kifejezett, megengedett, tolerálható bevitel fontos toxikológiai információ, de a gyakorlati szabályozás a $\mathrm{mg} / \mathrm{kg}$ élelmiszeregységben kifejezett határértéket veszi alapul [6].

A Magyar Honvédség személyi állománya is része a társadalomnak, így őket is érintik az élelmiszerekben előforduló vegyi anyagok, illetve azok egészségügyi kockázatai. A Magyar Honvédségben az élelmezés - táplálkozás higiénés kérdéseivel az egészségügyi szolgálat foglalkozik, az élelmezési ellátással kapcsolatos feladatokat a logisztika látja el. A parancsnokok feladata, hogy az élelmezésbiztonsági feltételek megismerésével és a megfelelő szakemberek bevonásával olyan rendszert alakítsanak ki, amely alkalmazásával hozzájárulhatnak a katonák elégedettségéhez, élelmezési kultúrájuk fejlesztéséhez [2]. Az élelmiszer-biztonság az elmúlt évtizedekben 
rohamos fejlődésen ment keresztül, de gyökerei egyidősek az emberiséggel. Ezt igazolja, hogy már az ókori társadalmaknál kívánalom volt, hogy az elfogyasztott élelmiszer az emberi egészségre ne legyen ártalmas. Példaként említeném, hogy Egyiptomban a papok megvizsgálták, hogy az elfogyasztandó áldozati állat húsa egészséges-e. A zsidó és a mohamedán vallás tiltja bizonyos állatok (pl. sertés) fogyasztását. Ezek a vallási szertartások, bár nem tudatosan, de már akkoriban is élelmiszer-biztonsági törekvések voltak. A fentiekből is következik, hogy az élelmiszer - táplálkozás - egészség szoros kölcsönhatásban van egymással [7].

\section{AZ EGÉSZSÉGES TÁPLÁLKOZÁS PIRAMISA}

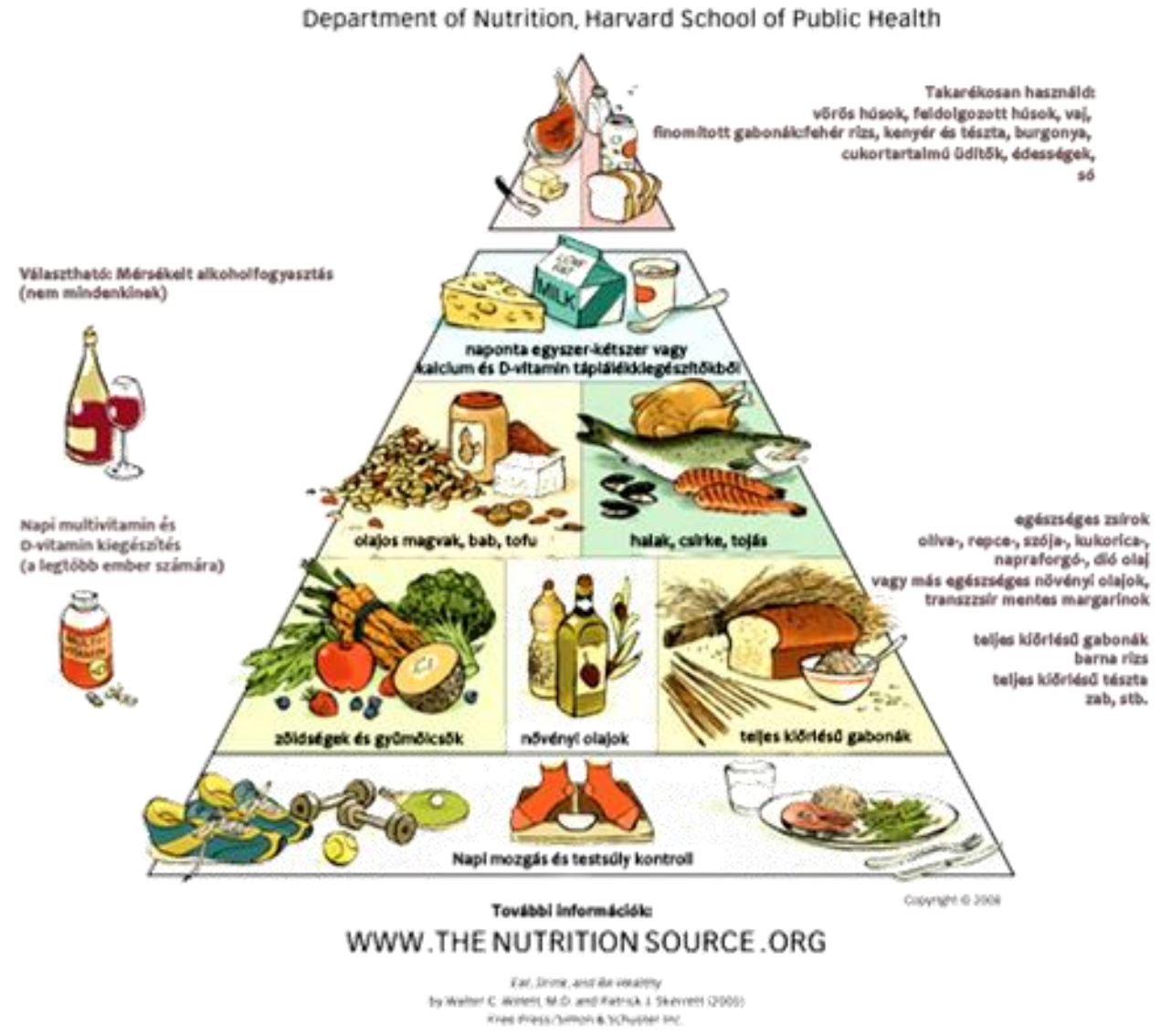

2. számú ábra. Az élelmiszer, a táplálkozás és az egészség kapcsolata [1]

Az élelmiszer-ellátás során nagyon fontos kérdés, hogy milyen hatással van az egészségünkre az elfogyasztott élelmiszer. Jogos elvá- 
rás, hogy az élelmiszer ne károsítsa, hanem támogassa szervezetünket. Az élelmiszerek, ételek emberi fogyasztásra való alkalmasságát a táplálkozás-biológiai és élvezeti értékük, valamint egészségügyi biztonságuk határozza meg. Az élelmiszerbiztonsági szabályok megszegése a fogyasztók számára komoly egészségügyi kockázattal járhat, súlyos, akár halálos betegségeket (élelmiszer-mérgezést) is okozhat. Az élelmiszer-biztonsághoz szorosan kapcsolódik az élelmiszer-higiénia, a biztonsághoz szükséges a különböző higiéniai szabályok betartása [8]. Ahogy már e cikk bevezetőjéből is kitünik, a biztonságos élelmiszerre vonatkozó igény az ókori társadalmaktól kezdve jelen van, de a XXI. században az élelmiszer-biztonságot számos tényező befolyásolja, amelyeket az alábbi fejezetben mutatok be.

\section{Az élelmiszer-biztonsági helyzet alakulását befolyá- soló tényezők}

Az élelmiszer-biztonsági helyzet alakulását sok tényező egymásra hatása alakítja. Ezen tényezők között vannak, amelyekben az emberi tevékenység vagy akár felelősség is szerepet játszik, de vannak az embertöl független faktorok is. Ezek befolyásolják táplálkozásunkat, közvetve pedig egészségi kockázatot is jelentenek. Az élelmiszerbiztonság alakulását befolyásoló tényezőket az alábbi ábra szemlélteti.

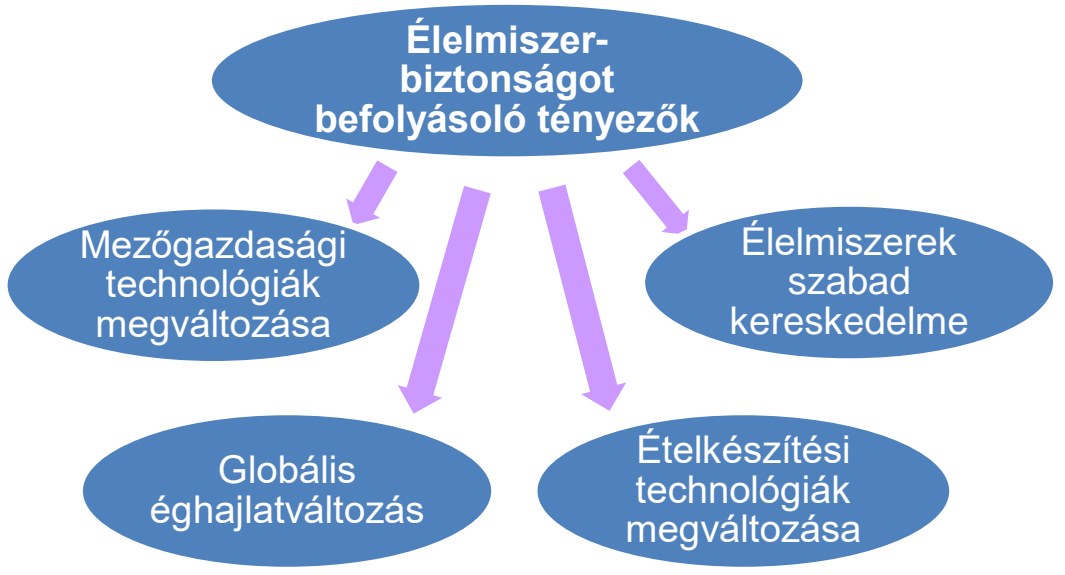

3. számú ábra. Az élelmiszer-biztonsági helyzet alakulását befolyásoló tényezők. Készítette: Horváth Lívia 


\subsection{Az élelmiszer-biztonság és a vegyi anyagok hatása az emberre}

Az egyre növekvő népesség élelmiszer-ellátása hagyományos termeléssel már nem oldható meg. A tömegtermelés miatt mind az állattenyésztésben, mind a növénytermesztésben egyre több vegyi anyagot alkalmaznak (pl. mezőgazdasági kemikáliák, hozamfokozók). Az alkalmazott vegyi anyagok maradványai a tápláléklánc útján szervezetünkbe kerülnek [8]. A megváltozott fogyasztói igények kielégítése tehát megköveteli az élelmiszer-technológiák változását. $A z$ új élelmiszer-technológiák megjelenése magában hordozza az élelmiszer-biztonság kockázatát is, az élelmiszerek különböző módon szennyeződhetnek. Az élelmiszer már nyersanyag formájában is tartalmazhat szennyeződést, de a termesztés, tenyésztés, forgalmazás során is, sőt az előkészítés, a gyártás és a forgalmazás alatt is kerülhet bele szennyeződés. A szennyeződések lehetnek biológiai, radiológiai, fizikai, vegyi eredetűek. A radioaktív szennyeződések többnyire véletlen baleset következményei. A biológiai szennyeződések során élő szervezet (mikroorganizmus) kerül az élelmiszerbe. A fizikai szennyeződés szabad szemmel is látható, többnyire egyszerüen (mosással, szitálással, válogatással stb.) eltávolítható. A kémiai szennyeződést szabad szemmel általában nem lehet látni, ezért egyszerű módszerekkel eltávolíthatatlanok. Ilyenek pl. a termőföldön a növényekbe kerülő peszticidek ${ }^{4}$, gyomirtók, az állattenyésztés során a húsba bejutó állatgyógyászati termékek, hozamnövelő szerek maradéka, a feldolgozás során az edényekből, bevonatokból kioldódó anyagok, a tárolás és forgalmazás során fertötlenítőszerek, környezeti szennyeződések [2]. Az élelmiszerbe jutó kémiai szennyeződéseket a későbbiekben részletesebben is bemutatom. Az élelmiszerekben előforduló kémiai szennyeződések nem választhatóak el szorosan a környezetszennyezéstöl, ami napjaink egyik legfontosabb és legégetöbb problémája. Ezt igazolja, hogy már a 2000-es években is több mint 10 millió vegyi anyagot regisztráltak, és mintegy 50 -100 ezerre tehető azoknak az anyagoknak a száma, amelyek a környezetbe kerültek [9].

A környezeti szennyeződések, a vegyi anyagok cirkulációval jutnak szervezetünkbe. A kémiai szennyeződések közül a nehézfémek, a vegyipari szerves és szervetlen vegyületek a legjelentősebbek. A nehézfémek közül az ólom-, a kadmium- és az arzénszennyeződéseket

4 A peszticid növényvédő szerek a növények védelmére szolgálnak, távol tartják a károsító élőlényeket. 
emelem ki, a higany által okozott, Japánból ismert Minamata ${ }^{5}$ [10] betegségre nem térek ki cikkemben. A kémiai szennyeződések egyik oka, hogy a mezőgazdaság gyors fejlödésével egyre inkább elterjedt a különböző mütrágyák használata. $A$ biológiai körforgás révén ezek az anyagok a növényi szervezetből az állati szervezetbe, majd a tápláléklánc utolsó láncszemeként az emberbe is bekerülnek. Az ártalmas vegyületek egy részét a növények termelik általában leveleikben és magvaikban, mert ezek egy része a növények védelmét is szolgálják a kártevőik ellen. Érdekességként emelném ki, hogy a burgonyában a héj alatt a téli tárolás folyamán a szolanin-tartalom jelentősen megnövekszik, ha pedig eléri a $180 \mathrm{mg} / \mathrm{kg}$ fölötti értéket, a krumpli étkezésre alkalmatlan lesz [11]. A mütrágyák a környezetet is károsítják, és a vízbe kerülve mérgezik azt. A talajjavítást szolgáló vegyületekkel, pl. a gyomirtókkal (herbicidek) és rovarirtókkal (inszekticidek), gombaölökkel (fungicidek) kapcsolatosan több kutatásra lenne szükség. Bizonyított, hogy a zöldségek, gyümölcsök felületén egyes esetekben a megadott határérték felett vannak jelen ezek a szennyezőanyagok. Ezen vegyületeknek nincs bizonyított élettani hatásuk, lehet azonban rejtett hatásuk sőt, egy-egy anyagnak több hatóanyaga is lehet, amelyek kölcsönhatásba léphetnek más ipari és háztartási vegyi anyaggal is. Felnőtt emberben okozhatnak anyagcserezavarokat, hormonális eltéréseket, csecsemőkben pedig methaemoglobinaemiát [11]. A különböző peszticideknek (pl. akaracid: atkaölő, herbicid: gyomirtó, inszekticid: rovarölö, rodenticid: rágcsálóirtó, ovocid: peteölő, fungicid: gombaölő szereknek) különböző kémiai csoportjaik vannak, és élettani hatásuk is eltérő.

A XXI. században nemcsak a növényvédő szerek használata terjedt el, az állattartásban is több mint 200 különböző vegyi anyagot használnak a hozam növelésére, az állatok gyógyítására. Praktizáló gyógyszerészként példaként elsősorban az állattartásban használt antibiotikumokat említeném, amelyeket a gépi fejés miatt kialakuló tőgygyulladásokra alkalmaznak. A különböző antibiotikumok kiválasztódnak a tejjel. Ha a tejet az antibiotikumok kiürülése alatt használják fel, az emberben antibiotikum-rezisztencia alakulhat ki. Az antibiotikumok azonban nemcsak a tejben, hanem tojásban és belsőségekben is megjelenhetnek. Az állattenyésztésben anabolikus szteroidok

5 Minamata városában fedezték fel Japánban a súlyos betegséget, melyet a helyi vegyi üzemből a tengerbe kerülő tisztítatlan hulladék okozott. A hulladékban lévő szervetlen higanyból az iszap baktériumai által toxikus metil higany keletkezett, amely súlyos idegrendszeri tüneteket váltott ki az embereknél. 
használata hazánkban hozamnövelés céljából még nem engedélyezett [11].

\subsection{Poliklórozott szerves vegyületek (Persistent Organic Pollutants)}

Az élelmiszereinkben előforduló vegyi szennyeződések közül a Perzisztens Szerves Vegyületek (a továbbiakban POP vegyületek) mindenütt jelen vannak a környezetben (ubiquiter szennyezők) [13]. Ezek a vegyületek koncentrációjuktól függően egészségügyi kockázatot jelentenek. Ide tartoznak a poliklórozott vegyületek és a poliaromás szénhidrogének. A 2004-ben hatályba lépett Stockholmi Egyezmény foglalkozik a POP vegyületek nemzetközi szabályozásával. Az Egyezmény 12 vegyület gyártását betiltotta vagy korlátozta. $A$ legismertebb vegyületcsoportok, amelyek mérgező hatásúak: az aldrin, dieldrin, endrin, heptaklór, klórdán, mirex, toxafén, DDT (diklórdifenil-triklóretán), ipari segédanyagok/szennyezők: poliklórozott bifenilek (PCB-k), hexaklórbenzol (HCB), poliklórozott dibenzo-dioxin (PCDD) és poliklórozott dibenzo-furán (PCDF). Ezt a listát a 2009-es genfi COP (Conference of Parties - Részes Felek Konferenciája) tovább bővítette, a teljesség igénye nélkül említve az achlordecon-t és a lindan-et. Az újonnan felvett kilenc vegyület között növényvédő szerek, ipari vegyi anyagok és ipari folyamatok melléktermékei találhatók [UNEP 2010]. 2010-ben további bővítésre tettek javaslatot, így a hazánkban is korábban elterjedt endoszulfán-t is korlátozhatják [14]. Ezeknek az anyagoknak a veszélyessége abban rejlik, hogy hosszú ideig perzisztálnak (megmaradnak) mind a környezetben, mind az élő szervezetekben, erősen lipofil (zsíroldékony) tulajdonságúak, így a zsírszövetben könnyen raktározódnak [13]. Ezt igazolja, hogy az Északi-sarkon élő jegesmedvék zsírszöveteiben, de az eszkimó nők anyatejében is a mai napig kimutathatók, annak ellenére, hogy a legközelebbi kezelt területek több ezer kilométeres távolságban találhatók [15]. (A táplálékláncon át is feldúsulnak, és széles toxikológiai spektrummal rendelkeznek, a légkörben, vizekben nagy távolságokra juthatnak el [13]. A poliklórozott vegyületek csoportjait a következő részben ismertetem (klórozott szénhidrogének, PCB, dibenzodioxinok, dibenzo-furánok).

\subsubsection{Klórozott szénhidrogén típusú növényvédő szerek}

A klórozott szénhidrogén típusú növényvédő szerek közül az egyik legismertebb az 1939-ben rovarölőként felfedezett diklór-difeniltriklóretán, a továbbiakban DDT, amelyet már betiltottak. A II. Világ- 
háború alatt a közegészségügy területén használták, a háború után pedig rohamosan elterjedt a mezőgazdaságban. Az 1950-es évektől kezdve egyre több hasonló típusú vegyület jelent meg, pl. a $\mathrm{HCH}$ (hexaklórhexán) izomerek, a HCB (hexaklórbenzol), aldrin, endrin, dieldrin, toxafén, heptaklór, endoszulfán, metoxiklór, amelyekröl kiderült, hogy feldúsulásuk a táplálékláncon át nyomon követhető. A statisztikai adatok alapján a lakosság zsírszövetében a DDT és metabolitjainak mennyisége az 1960-as években a 15-20 mg/kg-ot, az anyatejben a $340 \mathrm{mg} /$ litert is elérte. Az állatkísérletekben a DDT változatai közül az aldrin, endrin, dieldrin rákkeltő hatását igazolták. Ezen vegyületek jelentős részét hazánkban már betiltották, mivel már kis mennyiségben is károsítják az idegrendszert, nagyobb mennyiségben rákkeltő hatásukat is igazolták. Ma már inkább környezeti szennyező anyagnak számítanak, növényekben csak néhány szenynyezett terület esetében mutathatók ki [16]. Ezért ezekkel a vegyületekkel a továbbiakban nem foglalkozom. A klórozott szénhidrogén típusú vegyületek az ember idegrendszerét a Na pumpa megzavarásával károsítják. Általában - ahogy a POP vegyületek többi tagjánál is - inkább krónikus toxicitással kell számolni. Az akut toxicitásnál súlyos epilepsziás görcsök jelentkeznek, ez azonban ritka. A cikkemben terjedelmi okok miatt nem térek ki a többi eltérő kémiai szerkezetű peszticidekre, pl. a szerves foszforsavészterekre, a karbamátokra, fenol jellegü herbicidekre stb. Vegyületcsoporttól függően a peszticidek eltérő élettani hatást okozva fejtenek ki súlyos egészségkárosodást a szervezetre.

\subsubsection{Poliklórozott bifenilek (PCB)}

A poliklórozott bifenilek (a továbbiakban PCB-k) olyan kémiai vegyületek, amelyekben a klóratomok részben vagy teljesen átveszik a hidrogénatomok helyét a bifenil molekulán, amely egyszeres kötéssel összekapcsolt két benzolmolekulából áll. [13].A PCB-nek 209 módosulata van. A poliklórozott bifenileket (PCB-ket), összefoglaló néven kongénereknek nevezik. A kongéner elnevezés abból ered, hogy a vegyületekben hány klóratom van, és ezek milyen pozícióban vannak. A poliklórozott bifenilek (PCB-k) vázát két egymással szigmakötéssel kapcsolódó benzolgyürü képezi, melyben a hidrogénatomokat 1-10 db klóratom helyettesíti. 1966-ban mutatták ki először környezeti mintákban, de 4 évre rá világszerte korlátozták használatukat, majd a gyártásuk is megszűnt. Ennek ellenére napjainkban még mindig több tonna PCB-szerü anyag szennyezi a környezetet. A PCB-k térbeli szerkezetüktől és klórtartalmuktól függően immunszupp-resszívek, teratogének, ösztrogén hatásúak. PCB-nek kitettség esetén bőr- és 
szem- elváltozások, menstruációs zavarok léphetnek fel, csökken az immunitás, valamint májkárosodás is jelentkezhet. A terhes nők PCB kitettsége fejlődési rendellenességeket, különösen idegrendszeri károsodásokat okozhat a születendő gyermeknél. Állatkísérletekben orális kitettség mellett bizonyos PCB-k egereknél és patkányoknál májdaganatokat, ill. a belekben szöveti átalakulást okoztak [17]. A PCB-k és dioxinok biohozzáférhetősége a zsír- vagy olajtartalmú élelmiszerekből az emberi szervezetben több mint $75 \%$. A testben való eloszlás dózis- és kongéner-függő, tekintettel arra, hogy lassan metabolizálódnak, kiürülésük lassú. A PCB-k a zsírszövetben és a májban halmozódnak fel. Az emlősökben a PCB-k átjutnak a magzatba, és kiválasztódnak a tejjel. Az iparosodott országokban az étrendi $\mathrm{PCB}$ bevitel teszi ki a teljes $\mathrm{PCB}$ expozíció 90-95\%-át. Az Egészségügyi Világszervezet, a JECFA ${ }^{6} 1990$-ben a napi $P C B$ bevitelt az élelmiszerek útján $5-200 \mathrm{ng} / \mathrm{ttkg}$-nak becsülte. A teljes napi étrendek összes PCB tartalma alapján számolt napi bevitel Magyarországon $150 \mathrm{ng} / \mathrm{ttkg} / \mathrm{nap}$, tehát alatta marad az ipari országok felnőtt lakosságára vonatkozó becsült értékeknek (200 ng/ttkg/nap).

Az eredmények azonban azt jelzik, hogy a hazai lakosság szervezetébe rendszeresen jutnak be PCB-k, amit az emberi zsírszövetböl 1992-1994 között az OÉTI-ben végzett vizsgálati eredmények is alátámasztottak. A JECFA a rendelkezésre álló adatok figyelembevételével arra a következtetésre jutott, hogy a szokásos étrendi PCB bevitelnek nincs jelentős kockázata az emberi egészségre [18].

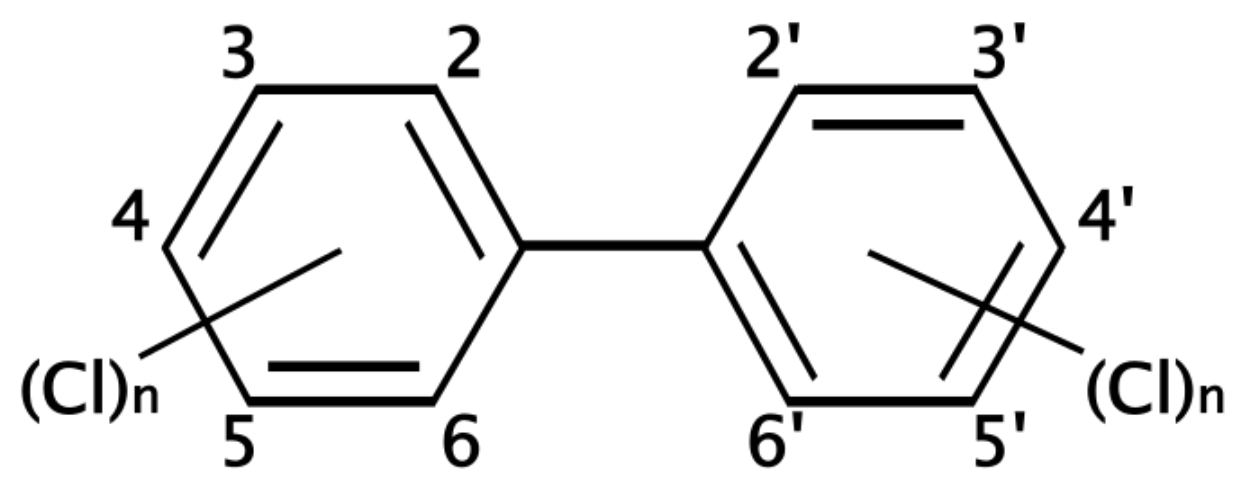

4. számú ábra. A PCB szerkezeti képlete [19]

6. JECFA - Joint FAO/WHO Expert Committee on Food Additive: Élelmiszer Adalékanyag Szakértő Bizottság 
Az átlagosnál nagyobb expozíció származhat abból, ha az étkezési szokások kulturális vagy regionális különbségei okán szennyezett termék kerül az étrendbe. Az állati eredetű élelmiszerek mindig több poliklórozott szennyezőanyagot tartalmaznak, így szignifikánsan nagyobb expozíciónak vannak kitéve azok, akik több májat stb. fogyasztanak. A gyermekek esetében, mivel kisebb a testtömegük, a napi bevitel arányaiban általában nagyobb. Különösen nagy PCB és dioxin expozíciónak vannak kitéve az anyatejjel táplált csecsemők[18].

\subsubsection{Poliklórozott p-dibenzo-dioxinok és poliklórozott dibenzofuránok}

Ebbe a vegyületcsoportba a poliklórozott dibenzo-para-dioxinokat (PCDD-k) alkotó 75 féle vegyület[19] és a poliklórozott dibenzofuránok (PCDF-k), összesen mintegy 135 féle vegyület tartozik. A dioxin a környezetben, az élelmiszerekben és az emberi szervezetben is megtalálható. A növényekbe a levegőböl kiülepedéssel jut, a talajból nem tudják felvenni. A dioxin forrása lehet az állatok szenynyezett takarmánya is. Zsírban oldódó anyag lévén az állati zsírszövetekben raktározódik. Krónikus expozíció patkányokban fototoxitást idéz elő.

A növényi élelmiszerek dioxin tartalma rendkívül kicsi. A háttérszint rendkívül alacsony, a levegőben fentogramm $/ \mathrm{m}^{3}$, a talajban, üledékekben nanogramm/kg nagyságrendü. ${ }^{7} \mathrm{Az}$ átlagos környezetben, vízi szervezetekben a dioxin koncentráció $<50 \mathrm{ng} / \mathrm{kg}$. Az állati eredetü élelmiszerekben 0,7-7 pg toxicitási egyenérték (TEQ) van jelen grammonként, zsírra számítva. ${ }^{8} \mathrm{Az}$ élelmiszerekben a dioxinok mindig a PCB-kel együtt fordulnak elő.

Az emberi zsírszövetben a dioxin háttérszint az átlag populációban $20 \mathrm{ng} / \mathrm{kg}$-ig terjed, a korral emelkedik. A napi dioxin bevitel magasabb a tejet és tejtermékeket, a tojást, a halat és a zsíros húsokat fogyasztók esetében [18]. Rendkívül jelentős az anyatejjel táplált csecsemők dioxin és PCB bevitele. Az expozíció a szoptatási idő hosszától és az anyatejben lévő dioxin koncentrációtól függ. Az ipari országokban a dioxinok átlagszintje a női tejben 10-35 pg/l TEQ/g tejzsír, a fejlődő országokban ennél kisebb. Az anyatejjel táplált csecsemő napi dioxin bevitelét az átlagos anyatejben található 16-40 pg/l TEQ/g zsír dioxin koncentráció alapján számolva 60-200 pg/l TEQ/ttkg-ra teszik. Mivel azonban a TDI koncepció az egész élettartam alatti bevitelre épül, nehéz ezt a fogalmat a csecsemőknél a szoptatási idő alatti kockázat

\footnotetext{
$7 \quad 1$ nanogramm $(\mathrm{ng})=10^{-9} \mathrm{~g}, 1$ fentogramm $(\mathrm{fg})=10^{-15} \mathrm{~g}$

81 pikogramm $(\mathrm{pg})=10^{-12} \mathrm{~g}$
} 
jellemzésére alkalmazni. A JECFA 1990-ben arra a következtetésre jutott, hogy az anyatejes táplálás a női tej PCB és dioxin tartalma miatt a potenciális veszély ellenére elönyös a csecsemő számára [18].

\subsection{Policiklusos aromás szénhidrogének [Policyclic aromatic hydrocarbons (PAH)]}

A policiklusos aromás szénhidrogének,(a továbbiakban PAH-ok) föként a szerves anyagok tökéletlen égésekor keletkeznek, mindenütt előfordulnak a környezetben. Több száz vegyület tartozik a csoportba, mindenütt megtalálhatók a környezetben. A PAH-ok stabil vegyületek, rendszerint különböző összetételü keverékekben fordulnak elő. A csoport egyes vegyületei rákkeltő hatásúak, de karcinogén aktivitásuk különböző lehet. Legfontosabb képviselőjük az erősen rákkeltő benzo(a)pirén. A policiklusos aromás szénhidrogén vegyületek egy részének a magzatot és az immunrendszert károsító, továbbá irritáló és allergizáló hatása is van [20]. Az emberi PAH bevitel fő forrásai a levegö, az élelmiszer, az ivóvíz és a dohányfüst. Környezeti szennyezőanyagként különösen halakban és halászati termékekben fordulhatnak elő. Zsírokat és olajokat tartalmazó élelmiszerekben, valamint azon élelmiszerek esetében, ahol a füstölési vagy szárítási eljárás jelentősebb szennyeződést okozhat, uniós határértéket rögzítettek a benzo(a)pirénre és négy $\mathrm{PAH}$ vegyület (benzo(a)pirén, benz(a)antracén, benzo(b)florantén és krizén) együttes mennyiségére vonatkozólag [21]. A benzo(a)pirént az IARC, ${ }^{9}$ a WHO (Egészségügyi Világszervezet) rákkutató ügynöksége humán karcinogénnek tekinti. A benzo(a)antracén, benzo(b)fluorantén és krizén 2B lehetséges humán karcinogén besorolást kaptak[20].

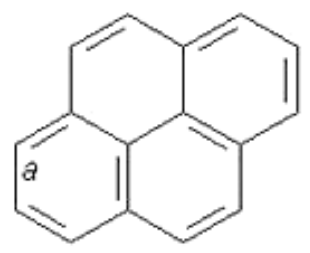

pirén (szintelen)

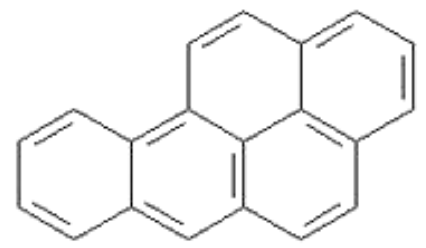

benz[a]pirén (halványsárga)

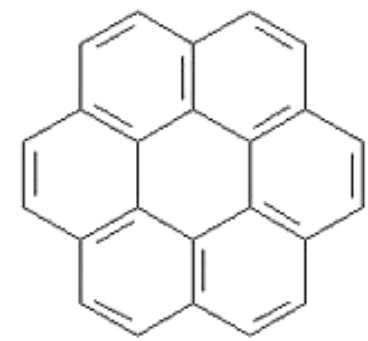

koronén

(sárga)

5. számú ábra. Kondenzált gyürük [22]

9 IARC - International Agency for Research on Cancer) Nemzetközi Rákkutató Ügynökség 
$A z$ anyagok genotoxikus rákkeltő tulajdonsága miatt szervezetbe kerülésük nem kívánatos. A bevitel azonban nem kerülhető el, de az észszerūen elérhető legalacsonyabb szintre kell szorítani. A rákkeltő tulajdonság sok esetben összefügg a gyürü kondenzálódásával, mert a gyürüs kondenzált vegyületek közül számosnak van rákkeltő tulajdonsága [22]. Veszélyes környezetszennyezők, irritatívak, szenzibilizálnak, emberre expozíciótól függően potenciálisan karcinogének [23].

Kémiai szerkezet szempontjából a gyűrüben hidrogént helyettesítő csoportok erősítik a karcinogenitást. A leginkább karcinogén vegyületek közé tartoznak az angulárisan anellált 4-, 5-, 6 gyürüs PAH-ok. Promoternek a kiindulási vegyületeket tekinthetjük, amelyekböl metabolikus aktiváció hatására képződik a szervezetben a kultimatív karcinogén anyag (oxid vagy peroxid típusú vegyület), ez reakcióba lép az örökítőanyaggal, DNS-sel és az RNS-sel, és károsítja azt [21]. A metabolitok a változatlan PAH-okkal együtt a szervezetből kiválasztás útján a vizelettel és a széklettel távoznak [23]. A zöldségek esetében a fajlagos felülettöl függ a PAH-ok koncentrációja, a leveles zöldségfélék (saláta, káposzta, paraj stb.) nagyobb mennyiségben koncentrálnak $\mathrm{PAH}$-okat, mint a kis fajlagos felületü zöldségfélék (pl. paradicsom). A szennyezett területről származó gabonafélék átlagos benzo/a/pirén, (továbbiakban $\mathrm{BaP}$ ) tartalma Magyarországon $2,1 \mu \mathrm{g} / \mathrm{kg}$, összes PAH tartalma (11 féle) 4,52 $\mu \mathrm{g} / \mathrm{kg}$ volt. Különbséget mutattak ki a gyümölcs- és zöldségfélék esetében is. Iparvidéken termelt alma héjában $\mathrm{pl}$. 30-60 $\mu \mathrm{g} / \mathrm{kg}$ benzo/a/pirént mutattak $\mathrm{ki}$, a tiszta levegőjü villanegyedben termelt alma héjának $0,2-0,5 \mu \mathrm{g} / \mathrm{kg}$-os értékével szemben. A salátában az OÉTI-ben mért BaP tartalom a termelöhely szennyezettségétöl függően $0,4-14 \mu \mathrm{g} / \mathrm{kg}$ között van. A legszennyezettebb értéket egy Százhalombatta környékéröl származó minta adta [18]. Gyökérzöldségek a talajból is képesek felvenni a benzo/a/pirént és egyéb PAH-okat, így pl. a sárgarépa PAH szennyezettsége arányos a talaj szennyezettségével. Ezt igazolja az OÉTI felmérése is, mert a szennyezett környezetben termelt sárgarépa benzo/a/pirén tartalma $3,5-8,5 \mu \mathrm{g} / \mathrm{kg}$, a nem szennyezett területen termelté pedig csak $0,3-0,4 \mu \mathrm{g} / \mathrm{kg}$. A hazai zöldség- és gyümölcsminták PAH tartalma a rendelkezésre álló adatok alapján viszonylag magas. A szintek a gyümölcsökben általában kisebbek, valószínüleg kisebb fajlagos felületüknek köszönhetően. Az állati eredetü élelmiszer nyersanyagokban elenyésző mennyiségben fordulnak elő a $\mathrm{PAH}-\mathrm{ok}$. A PAH ok nemcsak környezetünkböl, hanem élelmiszerkészítés során pörköléssel is a szervezetünkbe kerülnek. Ismert tény, hogy a füstölt élelmiszereket rendszeresen nagy mennyiségben fo- 
gyasztók esetében növekszik a gyomorrák veszélye. A PAH koncentrációja az élelmiszerben csökkenthető a füstszűrők és elektrosztatikus füstölés alkalmazásával. Magyarországon a jogszabályi előírás alapján a füstölt húsokban $1 \mu \mathrm{g} / \mathrm{kg}$, füstölt halakban legfeljebb $2 \mu \mathrm{g} / \mathrm{kg}$ BaP lehet [18].

\subsection{Szervetlen ipari mérgek, toxikus fémek és elemek}

A nehézfémek is környezetünk részét képezik, használjuk/feldúsítjuk őket különböző technológiákban, miközben szennyezzük velük a talajainkat és felszíni vizeinket, de ivóvizünkböl és táplálékainkból is bekerülhetnek az emberi szervezetbe a tápláléklánc útján. A technológia során a mai gyártású rozsdamentes edényben készített tengeri halak - pl. a kardhal vagy marlin steak - ebböl a szempontból a legnehezebben emészthetők [25]. A nehézfémek közé tartozik a teljesség igénye nélkül említve pl. higany $(\mathrm{Hg})$, króm $(\mathrm{Cr})$, kadmium $(\mathrm{Cd})$, kobalt $(\mathrm{Co})$, nikkel $(\mathrm{Ni})$, ólom $(\mathrm{Pb})$, ón $(\mathrm{Sn})$, réz $(\mathrm{Cu})$, cink (Zn), wolfram (W) [25]. A cikkemben a kadmiumot, az ólmot és az arzént elemezem terjedelmi okok miatt. A nehézfémek egy része nemcsak elemi formában, hanem különösen oldható sói alakjában erősen mérgező hatású lehet. Még nem egészen ismert módon a természetben - például a vizekben, üledékes kőzetekben, a levegőben, növényekben - feldúsulhat, ahonnan bekerül a táplálékláncba, az élelmiszerekbe és végső soron az emberi szervezetbe [10]. Érdekességként említeném, hogy egyes fémek (pl. a mangán) nem nélkülözhetők az élő szervezetek számára. Ismert tény, hogy a mangánenzimek alkotója, a kobalt a B12 vitamin központi eleme, a vas a hemoglobin alkotója, [26] a vanádium az alacsonyabb rendű növények számára fontos. A nehézfémek esetében ma már bizonyított, hogy az élő szervezetekbe milyen módon épülnek be a fémionok, de az, hogy egyes élő szervezetek miért képesek bizonyos fémeket akár milliószorosára feldúsítani, napjainkban is kutatás tárgyát képezi [25]. Éppen ezért fontos tudnunk, ismernünk azt a nehézfém koncentrációt, amelyet a szervezet elbír, amely nem okoz gondot, úgy is mondhatjuk, hogy küszöbérték, mert e felett már mérgezési tünetek léphetnek fel. Az alábbi részben ezért ismertetem az ólom, a kadmium és az arzén szervezetünk szempontjából megállapított küszöbértékét.

Ólom

A nehézfémek közül az ólom a tápláléklánc útján a talaj, a víz és a levegő közvetítésével jut a növényekre, az élelmiszer-nyersanyagokra, és így kerül az emberi szervezetbe. 
Az állati eredetü élelmiszereknek - a tej kivételével - magasabb az ólomtartalmuk, ez különösen a puhatestüekben, rákokban, halakban, ill. a belsőségekben fordul elö. A növényi eredetű élelmiszerekben az alábbi sorrendben nő az ólomtartalom: gyümölcs - zöldség - gabonafélék [10]. A JECFA a rendelkezésre álló toxikológiai és felmérési adatok figyelembe vételével az ideiglenes heti bevitelt (PTWI) 25 $\mu \mathrm{g} / \mathrm{ttkg}$-ban állapította meg. Az International Agency for the Research on Cancer (továbbiakban IARC) besorolása szerint az ólom 2 B kategóriás, tehát lehetséges humán rákkeltő, humán teratogén ${ }^{10}$ hatása bizonyított. A monitoring adatok alapján az ólomtartalmú üzemanyagok korlátozása és a környezetvédelmi intézkedések hatására folyamatosan csökken az ólomkoncentráció. Az OÉTI számításai szerint a hazai lakosság napi ólom bevitele az élelmiszerek révén $130 \mu \mathrm{g} /$ fő-re becsülhető, ami a JECFA által megállapított PTWI ${ }^{11}$ (tolerálható heti bevitel) $52 \%-a$ [18].

\section{$\underline{\text { Kadmium }}$}

Az élelmiszerek kadmiumtartalma a szigorú intézkedéseknek köszönhetően lassan csökkenő tendenciát mutat. A kadmium leginkább gabonafélékben és a zöldségekben, a burgonyában, a húsok közül pedig a méregtelenítő szervekben, pl. májban, vesében fordul elő. Ezek az élelmiszerek hazánkban a normál fogyasztó napi bevitelének több mint $80 \%$-át teszik ki. A kagylók és rákok, bár magas a kadmium tartalmuk, a magyar étrendnek csak kis részét képezik, ezért ezek nem növelik jelentősen hazánkban a kadmium bevitelét. $A$ kadmium a cereáliákban általában a magvak felületén lévő szennyeződés, de ezt a malmokban történt feldolgozás részben vagy teljesen eltávolítja. Ebböl következik, hogy a lisztben és a kenyérben alacsonyabb a koncentráció. A zöldségekben a kadmium szintjének $50 \mu \mathrm{g} / \mathrm{kg}$ alattinak kell lennie, ennél magasabb koncentráció található a leveles zöldségekben. A gyümölcsök kadmium koncentrációja alacsony, ezért ez nem terheli a szervezetet. A szennyezett területen termő gombák kadmium tartalma jelentős lehet. A talajból az olajos magvak, pl. a napraforgó és a lenmag is akkumulálják a kadmiumot, így menynyiségük a magvakban meghaladhatja az $500 \mu \mathrm{g} / \mathrm{kg}$-ot is, ami nem függ a talajban lévő koncentrációtól. Ugyanez vonatkozik a kakaóbabra is.

10 Fejlődési rendellenséget okozó

11 Provisional tolerable weekly intake (PTWI) 
A kadmium egyes élelmiszerekben kémiailag kötött formában van jelen, így a hozzáférhetősége korlátozott. Ezekben az esetekben valószínúsíthető, hogy a toxicitása is mérsékeltebb, de ezek tisztázása még további vizsgálatokat kíván. Az IARC besorolása alapján a kadmium és a kadmium-sók a humán rákkeltők 1. csoportjába sorolhatóak. A nemdohányzók számára a humán expozíció legfőbb forrása az étrend. A napi étrendi expozíció $23 \mu \mathrm{g}$, a maximális $53 \mu \mathrm{g}$ kadmium. $\mathrm{Az}$ OÉTI-ben végzett felmérés alapján a hazai napi becsült kadmium bevitel $28 \mu \mathrm{g} / \mathrm{fő}$ [18].

Arzén

Régóta ismeretes, hogy a tengeri élölényekben, a halakban, kagylókban, puhatestűekben, algákban van a legnagyobb arzén koncentráció, amely 0,5-50 mg/kg (nedves súlyra). A halak közül az édesvízi halak fogyasztása kedvezőbb, mert az arzénszintjük $10 \mu \mathrm{g} / \mathrm{kg}$ alatt szinte van. Az arzén a szárazföldön termő növényekben alacsonyabb koncentrációban fordul elő. A vágóállatok esetében a baromfi arzén tartalma magasabb, 0-100 $\mathrm{mg} / \mathrm{kg}$ tartományba tartozik, a többi állat arzénszintje hasonló, mint a növényeké. Egészségi szempontból az arzén III. és $V$. vegyértékü szervetlen formája a legtoxikusabb. Az IARC a szervetlen arzént humán karcinogénnek minősítette. A metilált formának azonban, mint például a dimetil-arzenátnak kicsi az akut toxicitása, míg a halakban és rákfélékben előforduló legfontosabb arzén-fajta, az arzenobetain, nem tekinthető toxikusnak. A rákokban, kagylókban és tengeri vízinövényekben a dimetil-arzenilribóz származékok, mint "arzén-cukrok" fordulnak elő. Mérgező hatásuk az emberre részleteiben még nem ismert. Az élelmiszerekben a szerves arzénvegyületek vannak túlsúlyban, a halak arzéntartalmának csak néhány \%-a szervetlen. A JECFA a PTWI-t szervetlen arzénra $15 \mathrm{mg} / \mathrm{ttkg}$-ban állapította meg [18]. A szervetlen ipari mérgezések jelentősége ma is nagy. A heveny és idült mérgezések felismerése, valamint a megelőző intézkedések az egész társadalom számára fontosak [10]. Az élelmiszerbe kerülő különböző vegyi szennyeződések, az élelmiszer-technológia megváltozása a civilizációs megbetegedések növekvő számának egyik oka lehet. Ezt támasztja alá, hogy napjainkban Mishio Kushi Rákmegelőző diéta címü könyvében Tompa Annához hasonlóan - a földművelés és az élelmiszertechnológia átalakulásával indokolja a civilizációs megbetegedések növekvő tendenciáját [27]. A helyzetet súlyosbítja, hogy nemcsak a termelés minősége és mennyisége változott meg, hanem a lakosság étkezési, fogyasztási szokásai is. A rohanó életmód miatt előtérbe került a finomított, gyorsan felszívódó szénhidrátok fogyasztása, a 
túlzott mértékü kalóriabevitel, a kapkodó, gyors étkezés, az egyhangúság, az adalékanyagokkal teli ételek, valamint a különböző élvezeti szerek (üdítő italok, kávé stb.) fogyasztása [9].

A természeti katasztrófáknál, utazásoknál, missziókban, műveleti területeken kétségtelenül előnyös a tartósított élelmiszerek fogyasztása, de napjainkban egyre inkább számolni kell a népesség körében az instant és tartósított ételekre adott allergiás reakciók, valamint ételintoleranciák növekvő számával. A következő részben a mesterségesen hozzáadott komponensek közül elsősorban az adalékanyagokat ismertetem.

\subsection{Mesterségesen hozzáadott komponensek}

Az élelmiszerekhez adott adalékanyagok egy részét pl. tartósításra használják. Adalékanyagnak nevezünk minden olyan természetes vagy mesterséges anyagot - tekintet nélkül arra, hogy van-e tápértéke vagy sem -, amelyet élelmiszerként önmagában nem fogyasztanak, alapanyagként nem használnak, hanem az élelmiszerhez az elökészítés, a kezelés, a feldolgozás, a csomagolás, a szállítás vagy a tárolás folyamán adnak hozzá abból a célból, hogy a termék érzékszervi, kémiai, fizikai és mikrobiológiai tulajdonságait kedvezően befolyásolja. Hozzáadása azt eredményezi vagy eredményezheti, hogy önmaga vagy származéka az élelmiszer összetevőjévé válik [11]. Az alapvető élelmiszeradalék-csoportok:

- színezékek: E100-E199;

- tartósítószerek: E200-E299;

- antioxidánsok: E300-E399;

- emulgeálók, stabilizálók, sürítők és zselésítők: E400-E499.

A fentiekböl is látszik, hogy a feldolgozott élelmiszerek csomagolásán az adalékokat az $\mathrm{E}$ betüvel és egy kóddal jelölik. Ezek ízesítők, édesítők, színezékek, antioxidánsok, emulgeátorok stb. Van azonban néhány adalékanyag, amelyet külföldön betiltottak, mert csak később derült ki károsító, toxikus, mutagén, karcinogén hatásuk. Például a WHO vizsgálata szerint az E161g (kantaxantin) májkárosodást, az E413 (tragantmézga) pedig erős allergiát válthat ki. Ma Magyarországon az adalékanyagok jelenlétét az élelmiszerek csomagolásán fel kell tüntetni. Az élelmiszer-adalékok veszélyesek is lehetnek, ha egy ember allergiás rá, és arról nem tud [11]. 


\subsection{A technológiai eredetü szennyező anyagok. Feldolgozás, felhasználás, csomagolás, ételkészítés során elöforduló károsító tényezők és hatásuk}

A XXI. században a technológiai (élelmiszeripari, konyhai, tárolási, csomagolási) eljárások során is keletkezhetnek káros anyagok, illetve bizonyos komponensek elbomolhatnak vagy feldúsulhatnak. A friss húsokban található aktív amin tartalom egyes húsokban érlelés során olyan mértéküre emelkedhet, hogy fogyaszthatóságuk megkérdőjelezhető [11]. A PVC csomagolású élelmiszerek mikrohullámú újramelegítése a csomagolóanyaggal együtt nem tanácsos az ártalmas anyagok jelentős koncentráció-növekedése miatt. Fontos megemlíteni a közvetlen, direkt sütés (például a grillezés) során keletkező mutagén hatású anyagokat (metilglioxál, diacetil) [23]. A műanyagok nem toxikusak, nem is oldódnak. A toxikológiai megítélésnél a kioldható anyagok toxicitása meghatározó. A mủanyag gyártásának kiindulási anyagai a monomerek, közülük a vinilklorid (VC), akrilnitril, sztirol rákkeltő vegyületek. A visszamaradó monomerek és oligomerek azonban oldhatóak. A végtermékben szennyezésként visszamaradt monomerek és oligomerek megfelelő utókezeléssel a legtöbb müanyagból csaknem teljesen eltávolíthatók.

\subsection{Az éghajlatváltozás hatása az élelmiszerekre}

Az ember az urbanizációval, a tömegtermeléssel a természeti környezet folyamatos változását eredményezi, környezetünkbe egyre több vegyi anyag kerül.

A környezetszennyezés kapcsolatba hozható a globális éghajlatváltozással. A klímaváltozás és az ennek következtében kialakuló egyre szélsőségesebb időjárás kihatással van a népesség ivóvízellátására és élelmiszerbiztonságára, közvetve pedig egészségi állapotára. Az elmúlt 100 évben felére csökkent az erdős területek száma; a fafajták, valamint az állatok tizedét fenyegeti a kihalás [32]. Sajnos ez a tendencia várhatóan tovább fog tartani. A környezetszennyező anyagok közül számos mutagén vagy karcinogén anyag kerül a levegőbe, amely komoly egészségügyi kockázatot jelent [26]. A lassú éghajlatváltozáshoz a XXI. században az ember is hozzájárul, mert a természetes környezetet egyre inkább mesterséges környezetté alakítja át, és ez az ökológiai egyensúly folyamatos megbomlását eredményezi. Ez nagy kihívást jelent az adaptáció szempontjából a Föld élőlényei számára, beleértve az embert is. A globális klímaváltozással nő az ízeltlábúak, valamint a rágcsálók által terjesztett megbete- 
gedések száma, és távoli földrészek betegségei jelenhetnek meg hazánkban is. A magasabb hömérsékleten a mikrobák gyorsabban szaporodnak, így növekvő tendencia figyelhető meg az élelmiszerek és az ivóvíz okozta fertőzések számában. A nyári időszakban a magasabb hőmérséklet miatt az összes bejelentett élelmiszer-fertőzés 70\%-át Salmonella fertőzések okozzák [32]. A globalizáció nemcsak a természeti jelenségek változására hatott, de az utóbbi csaknem 30 év társadalmi változásait is befolyásolta, így például megalakult az Európai Unió, amelynek tagállamai között gyakorlatilag megszűntek a határok, létrejött az élelmiszerek szabad áramlását biztosító egyezmény.

\subsection{Az élelmiszerek szabad áramlása}

Az EU tagországaiban az áruk szabad áramlása egyenlő értékesítési feltételeket teremt valamennyi tagország piacán, bármely tagállam vállalata számára. Hazánkban, mint uniós tagországban is érvényesül az áruk szabad kereskedelme, amely tagállami szinten számtalan élelmiszer-biztonsági kérdést felvet. Az elv bevezetésének alapja a Közösségen belül az egyenlő értékesítési feltételek biztosítása volt, viszont a tagállamok azon jogát is érvényesíteni kellett, hogy közegészségügyi, biztonsági megfontolásból bizonyos termékeket kizárhassanak saját piacukról. Ennek megvalósítására jogszabály tilthatja meg bármely tagállamok közötti behozatalt vagy kivitelt vám, ill. ezzel azonos hatályú díj kiszabásával, továbbá bármely behozatalra vagy kivitelre vonatkozó mennyiségi korlátozás, vagy azzal azonos hatású intézkedés bevezetésével (Alapító Szerződés 25. 28. és 29. cikk).

Az alapító szerződés azonban lehetőséget adott arra is, hogy figyelmen kívül hagyhassák az előzőket a tagállamok, amennyiben a termék behozatala a közerkölcsöt, a közbiztonságot, az emberek, az állatok és a növények egészségét és életét sértheti vagy veszélyeztetheti (Alapító Szerződés 30. cikk). A közösségi szabályozás élelmiszer-biztonsági rendelkezéseinek célja egységes védelmet biztosítani a fogyasztó számára. Ezzel párhuzamosan ugyanakkor lehetősége van a tagállamnak, hogy a közösségi szabályozásnál szigorúbb elöírásokat alkalmazzon.

Élelmiszer-biztonsági szempontból veszélyt jelent a nemzetközi turizmus, az élelmiszerek mozgása országok vagy akár kontinensek között, amely hozzájárulhat a kórokozók, járványok akár világméretű terjedéséhez. Erre példaként említeném, hogy a mézekben is találha- 
tóak természetes eredetű káros anyagok, amelyek más növényekből kerülnek a mézekbe, és ott az átalakulás során feldúsulnak [33]. Magyarországon nincsenek ilyen mézek, de importból (Brazília, Japán, Nepál és Grúzia) ellenőrzés nélkül hazánkba kerülhetnek, és komoly egészségkockázatot jelentenek. Ezek a mézek nem csak mérgezést, de súlyosabb esetben még halált is okozhatnak [33]. A rossz minőségü vagy akár romlott élelmiszerek felhasználása heveny ételmérgezésekhez, illetve ételfertőzésekhez vezethet. A betegségek kialakulását okozhatják a közvetítő élelmiszerek, valamint a technológiai és higiénés hiányosságok is.

Tekintettel arra, hogy a Magyar Honvédség nagy létszámmal múködő zárt közösségnek tekinthető, ezért a megbetegedések is tömegesen fordulhatnak elő. Az élelmiszereknek minőségi és biztonsági szempontból is a honvédségen belül is meg kell felelnie a követelményeknek, amelyet csak hatékony élelmiszer-biztonsági és minőségi rendszerek segítségével lehet megvalósítani.

\section{Az élelmiszer-biztonság jogi szabályozása}

Az élelmiszer-fertőzések kivédésére az élelmiszer-biztonság érdekében a hatóságok hazánkban és uniós szinten is különböző jogszabályokat vezettek be. Cikkemben terjedelmi okok miatt csak a legjelentősebb jogszabályokat emelem ki. Az élelmiszer-biztonság gyökerei a 80-as évekre nyúlnak vissza, a NASA és a hadsereg az USAban ekkor dolgozta ki a HACCP rendszert, amely a minőségbiztosítási rendszerek között az egyik legismertebb (Hazard Analysis Critical Control Point, vagyis Veszélyelemzési Kritikus Szabályozási Pontok). Ez az egészségkárosodások megelőzésére kifejlesztett rendszer, amely az élelmiszer előállításra, feldolgozásra, valamint a vendéglátásra, közétkeztetésre és kereskedelemre vonatkozik. A rendszer kidolgozásának a célja az volt, hogy az ürhajósok biztonságos, szennyeződéstől mentes élelmiszereket vigyenek az ürbe. A konzervipari termékeknél1973-tól alkalmazták, az általános élelmiszeriparban csak az 1980-as évektöl kezdett el szélesebb körben is elterjedni [34]. Az Egészségügyi Világszervezet (WHO) által 1993-ban kiadott Codex Alimentarius (Élelmiszerkönyv) irányelve a HACCP-t kiterjesztette az élelmiszer-biztonság kémiai, fizikai és biológiai eredetű veszélyeire is. Az EU országaiban 1995-től kötelező a HACCP bizonyos alapelveinek alkalmazása. Hazánkban 2002. január 1-től kötelező a rendszer müködtetése [34]. A HACCP alkalmazásának útmutatóit a 
Magyar Élelmiszerkönyv MÉ 2-1/1969 része tartalmazza. A HACCP egy olyan rendszer, amely meghatározza, értékeli és szabályozza az élelmiszer-biztonság szempontjából jelentős veszélyeket. Az Európai Unió országaiban a HACCP-t 1995 óta alkalmazzák már az élelmiszergyártók és a vendéglátásban résztvevők számára is, amely 2002. január 1-től kötelező. Az alkalmazása a vendéglátás és közétkeztetés területén a 2004-es EU csatlakozási időpont után kötelező. A Magyar Honvédség is már 2002. évtöl alkalmazza a HACCP-t rendszert. Az EU-hoz való csatlakozás jegyében módosítva lett az élelmiszerekröl szóló 2003. évi LXXXII. törvény.

A jelenleg hatályos szabályozást az élelmiszerláncról és hatósági felügyeletről szóló 2008. évi XLVI. törvény biztosítja. A törvény célja a fogyasztók egészségének, a fogyasztók és az élelmiszervállalkozások érdekeinek védelme, a piaci verseny tisztaságának biztosítása, az élelmiszer-előállítás és -forgalmazás általános feltételeinek szabályozása, az engedélyezés és a bejelentési kötelezettség tekintetében eljáró hatóságok nevesítése. A magyar szabályozás kialakítása során a FAO/WHO által kiadott Codex Alimentarius és az (EP Európai Parlament) és Tanács 178/2002/EK számú, az élelmiszerjog általános elveiről és követelményeiről szóló rendelete, az Európai Élelmiszer-biztonsági Hatóság létrehozásáról és az élelmiszerbiztonságra vonatkozó eljárások megállapításáról volt irányadó. A Codex Alimentarius mintájára alkották meg a Magyar Élelmiszerkönyvet. A FAO (Food and Agricultural Organization of the United Nations - az ENSZ Élelmezési és Agrár Szervezete) és a WHO (World Health Organization - az Egészségügyi Világszervezet) által közösen létrehozott Codex Alimentarius Bizottság által megfogalmazott általános irányelvek meghatározzák az élelmiszerlánc tagjainak szerepét az élelmiszer-biztonság területén. A 178/2002/EK rendelet „az élelmiszerjog általános elveiről és követelményeiről az Európai Élelmiszer-biztonsági Hatóság létrehozásáról és az élelmiszerbiztonságra vonatkozó eljárások megállapításáról" meghatározza az általános élelmiszer-biztonsági követelményeket, amelyek szerint élelmiszer nem kerülhet forgalmazásra, ha az nem biztonságos. Az élelmiszeripari vállalkozók kötelesek kivonni a nem biztonságos élelmiszereket a piacról.

Az élelmiszerekröl szóló 2003. évi LXXXII. törvény az élelmiszereknek a Magyar Köztársaság területén történő előállításáról, illetve forgalomba hozataláról szól. Az első mondatból egyértelműen következik, hogy a törvény hatálya valamennyi, Magyarországon elöállított (exportra is szánt), valamint forgalomba hozott (importból is szárma- 
zó) élelmiszerre terjed ki. A törvény nem rendelkezik az élelmiszerek magánháztartásban, saját fogyasztásra történő előállításáról. A törvény meghatározza az élelmiszer fogalmát, valamint azt, hogy $\mathrm{mi}$ nem minősül élelmiszernek [41]. A hatósági élelmiszer-ellenőrzést a szakterületek szerint az élelmiszerbiztonsági szerv, az egészségügyi államigazgatási szerv, a fogyasztóvédelmi hatóság, a növényvédelmi szerv látja el. Érdemes megemlíteni a Magyar Élelmiszerkönyvet is, amely az egyes élelmiszerekre, illetve az élelmiszerek vagy élelmiszer-összetevők egyes csoportjaira vonatkozó élelmiszer-minőségi, élelmiszer-jelölési és élelmiszer-biztonsági kötelező előírások gyűjteménye (2008. XLVI. törvény, 66§.). A Magyar Élelmiszerkönyv Bizottság dolgozza ki a Magyar Élelmiszerkönyv előírásainak és irányelveinek tervezetét. A Magyar Élelmiszerkönyv I. kötete tartalmazza az Európai Unió kötelező jogi aktusainak átvételével készült, az élelmiszerek vagy élelmiszer-összetevők egyes csoportjaira vonatkozó élelmiszer-minőségi, élelmiszer-jelölési és élelmiszer-biztonsági (élelmiszer-higiéniai), illetve a nemzeti termékelőírásokra és rendelkezésekre vonatkozó kötelező elöírásokat. A II. kötetében a nemzetközi szervezetek ajánlásainak és a hazai adottságok figyelembevételével készült ajánlott irányelveket találjuk. A III. kötete - a Hivatalos Élelmiszer-vizsgálati Módszergyüjtemény - az Európai Közösség irányelveinek átvételével készült vizsgálati módszer előírásokat, továbbá ajánlott vizsgálati módszer irányelveket tartalmazza [35].

\section{1. Az Európai Unió élelmiszer-biztonsági politikája}

Alapja: „a termőföldtől az asztalig” minden folyamatot lefedő, integrált megközelítés.

Célja: a következetes, eredményes és dinamikus élelmiszerpolitika kialakítása.

Az Európai Unió élelmiszer-biztonsági politikájának fő célkitűzése az emberi egészség és az élelmiszerekhez kapcsolódó fogyasztói érdekek legmagasabb szintű védelmének biztosítása. Mindezek érdekében az EU átfogó élelmiszer-biztonsági szabályozást alakított ki, amelyet a változó követelményeknek megfelelően folyamatosan fejleszt és módosít.

Az élelmiszerek biztonságát az Európai Unió számos szabállyal védi. Általános szabályok vonatkoznak az adalékanyagokra, ízesítőkre, szennyező anyagokra, címkézésre, tápérték feltüntetésére. Az élelmiszer biztonságosságáért és minőségéért az élelmiszer előállító- 
ja, nem hazai előállítású élelmiszer esetében pedig az első magyarországi forgalomba hozó - a fogyaszthatósági, illetve a minőségmegőrzési időtartam lejártáig - felelős. Az élelmiszerek címkézésére vonatkozó közösségi szabályozás alapja a 2000/13/EK irányelv, melynek célja, hogy a fogyasztók minden, a termékkel kapcsolatos információról tudomást szerezzenek. A jelenlegi 2000/13/EK számú irányelv tartalmaz minden szükséges információt, amit az élelmiszereken jelölni kell. A címkén magyar nyelven kell feltüntetni a termék nevét, összetevőit, az összetevők mennyiségét, az elörecsomagolt élelmiszerek esetén a nettó mennyiséget, azt az időpontot, ameddig minimum eltartható (mikrobiológiai szempontból gyorsan romló élelmiszerek esetében a pontos dátumot).

Az Unióban valamennyi zöldség-gyümölcs terméknek minimumként épnek, egészségesnek, megbízható piaci minőségűnek kell lennie, feltüntetve a csomagolásán a származási országot, amelyet a tagállamok a kereskedelem valamennyi lépcsőfokán ellenőrizhetik. Adott termékekre ennél bővebb tartalmú szabvány is alkalmazható. $A$ termékek négy minőségi kategóriába sorolhatók: extra, I., II. és III. osztályba. Kívánalom, hogy a kereskedelembe kerülö áruk nagy részét az I. osztályú termékek képezzék. A II. csoportba sorolt terményekkel szemben elöírás, hogy megfeleljenek a minimumkövetelményeknek, legyenek piacképesek. A III. osztályú áruk kereskedelmi forgalma hazánkban sincs engedélyezve. A kötelező elöírások méretelőírásokat is tartalmaznak. Ezeket a termék jellemzőinek megfelelően határozzák meg. Így vonatkozhatnak az átmérőre (pl. almánál), a tömegre (pl. salátánál), a hosszra, vagy ezek kombinációjára. A hazai terményeket a Magyar Élelmiszerkönyv elöírásai alapján osztályozzák a megyeszékhelyeken működő Állategészségügyi és Élelmiszer Ellenőrző Állomás szakértői. Exportra szánt zöldséggyümölcs esetében a minőségi kategóriákat tartalmazó bizonyítvány kiállítása kötelező, e nélkül nem kerülhet forgalomba magyar áru az EU-ban [41].

Az élelmiszer-biztonsággal foglalkozó nemzetközi szervezetek közül a legfontosabbak: az élelmiszer-hamisítással kapcsolatos információs hálózat és a Food Fraud Network. Ez biztosítja a határon átnyúló, élelmiszer-hamisítással kapcsolatos ügyek információcseréjét, célja közösen fellépni és megakadályozni az élelmiszeripari termékek hamisítását [44]. Az EU tagországokban az élelmiszerekre és a takarmányokra gyorsvészjelző rendszer müködik, ez az RASFF (Rapid Alarm System for Food and Feed) rendszer [38]. A rendszeren keresztül jelentik a tagállamok a Bizottságnak az élelmiszerekből és 
takarmányokból származó, az emberi egészséget közvetve vagy közvetlenül érintő veszélyt. A legföbb különbség az RASFF és az FFN között az, hogy az RASFF-el szemben az FFN olyan ügyekkel foglalkozik, amelyek egészségügyi kockázattal nem járnak, és kimerítik az élelmiszer-hamisítás definícióját (vagyis szándékos és profitszerzési célzatú ügyek). Az élelmiszer-biztonság szigorú szabályozása ellenére szándékos visszaélésekkel, hamisítással (pl.: méz), tisztességtelen piaci magatartással kell szembenézni. Külön kihívást jelent az új előállítási és kereskedelmi formák elterjedése, amelyeket a hagyományos kereskedelmi rendszerekkel már nem lehet kézben tartani. A szabályozás ellenére az élelmiszerüzletekben megjelennek olyan termékek, amelyek a fogyasztó számára komoly egészségügyi kockázatot jelentenek. Ezt bizonyítja, hogy importált dán előállítású marcipános csokoládéban pl. mủanyagot találtak 2017-ben, erre a NÉBIH hívta fel a figyelmet, a gyártó elrendelte a termék azonnali visszahívását [45].

\section{Konklúzió:}

A XXI. században a környezetünk szennyezettségét okozó vegyi anyagok a táplálékláncon keresztül szervezetünkbe kerülve komoly veszélyt jelentenek az egész társadalom számára. Az élelmiszerbiztonság célja egészségünk megóvása, hogy az egészséges táplálkozás alapjául szolgáló élelmiszerek minden tekintetben megfeleljenek az egészségügyi előírásoknak.

A szigorú szabályozás ellenére a szándékos visszaélésekkel, tisztességtelen piaci magatartással kell szembenéznünk.

A növénynemesítés során olyan fajtákat célszerü létrehozni, amelyek ellenállnak a kártevőknek. Ezek azonban humán toxikológiai problémát is jelentenek. Ezen anyagok humán toxicitásáról keveset tudunk, ezért további kutatást igényelnek.

Az élelmiszer-biztonság területén ugyancsak további kutatást igényelne a mikotoxinok emberi szervezetre gyakorolt hatása, a mikotoxinok korszerübb eljárásokkal történő kimutatása.

A felszolgált élelmiszerek minősége, változatossága a haderő tagjainál sem csak az állomány elégedettségét szolgálja, de hozzájárul a harcképesség megőrzéséhez is. 


\section{Irodalomjegyzék:}

1. Belton, Peter: Chance, risk, uncertainty and food. Trendsin Food Science and Technology, 2001, 12, 32-35. p.

2 Az 1995. évi XC. törvény Az élelmiszerekröl

URL:http://elfiz2.kee.hu/e code/elmtorveny.html Letöltés: 2017.11.27

3. Lévainé Szabó Ildikó, Kiss Dávid: Az élelmiszer-ellátás biztosítása a Magyar Honvédségben. Katonai Logisztika 2017. I-II. szám

4. Józan Péter: A halandóság alapirányzata a 20. században, és az ezredforduló halálozási viszonyai Magyarországon. Magyar Tudomány 2002 (4), 419-439.

http://www.matud.iif.hu/02apr/jozan.html. Letöltés:2017.12.08

5. Horváth Lívia: A műveleti területen szolgálatot teljesítők egészségének védelme, immunrendszerük erősítése, különös tekintettel a táplálkozásra. Hadtudományi szemle 2017.X.2 szám

6. Kovács Ferenc: Agrártermelés Élelmiszer-minőség Népegészségügy Bp. 2002. Magyar Tudományos Akadémia Agrártudományok Osztálya

7. Pleva Györgyi: Az élelmiszer-biztonság aktuális kérdései http://portal.nebih.gov.hu/Letöltés: 2017.11.28.

8. Élelmiszer-higiénia, Élelmiszer-biztonság, Laczay Péter MTA folyóirata

http://www.matud.iif.hu/2012/01/02.htm Letöltés:2017.10.28

9. Tompa Anna: Sérült világunk egészsége: Budapest: Springmed Kiadó, 2014.ISBN 9789639656789

10. Ádány Róza: Megelőző Népegészségtan: Megelőző orvostan és népegészségtan, Medicina Könyvkiadó Zrt. 2011

11. dr. Szabó $P$. Balázs: Élelmiszerek és az egészséges táplálkozás TÁMOP-4.1.1.C-12/1/KONV-2012-0014 „Élelmiszer-biztonság és gasztronómia vonatkozású egyetemi együttmüködés, DE-SZTEEKF-NYME „projekt segítségével jött létre 2012

12. Stefanovits Pál, Filep György, Füleky György: Talajtan, Mezőgazda Kiadó 1999

13. Dr. Sohár Pálné és Dr. Matyasovszky Katalin: A perzisztens szerves vegyületek (POP-ok) jellemzése, előfordulása, élelmiszerekben mérhető szintjeik, étrendi bevitelük és egészségügyi kockázatuk 
14. Michio Kushi: Rákmegelőzős és gyógyító diéta. Budapest, Kossuth Kiadó, 2013. ISBN: 9789630975063

15. POP jellegű növényvédőszer-hulladékok Közép-Kelet-Európa, Kaukázus és Közép-Ázsia országaiban Biokontroll folyóirat URL: https://www.biokontroll.hu/pop-jelleg-noevenyvedoeszerhulladekok-koezep-kelet-europa-kaukazus-es-koezep-azsiaorszagaiban/ Letöltve: 2017.11.28

16. http://kockazatos.hu/kislexikon/pop-lista Letöltés: 2017.11.20

17. Oláh Eszter: Klórozott típusú szénhidrogén vegyületek http://enfo.agt.bme.hu/drupal/node/6236 Letöltés: 2017.11.30

18. Stefanovits Pál, Filep György, Füleky György: Talajtan Mezőgazda Kiadó

19. http://kockazatos.hu/anyag/polikl\%C3\%B3rozott-bifenilekLetöltve:2017.10.25

20. Rodler Imre: Táplálkozás és élelmiszer-biztonság, különös tekintettel a dagnatos megbetegedésekre PhD 2004

21. https://chem.nlm.nih.gov/chemidplus/rn/262-12-4 Letöltés: 2017.12.01

22. http://portal.nebih.gov.hu/-/a-policiklusos-aromas-szenhidrogenekrol Letöltés: 2017.12.01

23. http://kockazatos.hu/anyag/policiklusos-arom Letöltés:12.02.03.

24. Markó László: Educatio Szerves kémia ,I. Társadalmi Szolgáltató Nonprofit Kft

25. Tóth Gábor: Tudomány és életmód Allergia és Candida kalauz, Pilis Bet Bt. 2003

26. Kertai Pál: Megelőző Orvostan, Medicina kiadó Budapest 1999, ISBN:9632422248

27. Tompa Anna: Egészség és globalizáció, Springmed Kiadó Budapest 2004

28. http://portal.nebih.gov.hu/-/kerdezz-felelek-az-elelmiszeradalekanyagokrol

29. http://mek.oszk.hu/01200/01215/html/tartosito.htm Letöltve: 2017.12.03.

30. Orvosi kézikönyv a családban, Melánia Kiadó 2004 
31. Braun Tibor, Umami: Az ízfokozó ötödik alapíz. Egy korszakos jelentőségü, korai japán tudományos felfedezés és találmány, Magyar Kémikusok Lapja, 2017. 1. 17

32. Ember István, Tóth József, Pál Viktor: Egészségföldrajz, Medicina Kiadó 2010

33. Nagy Klára: Európai Unió egységes piacának és élelmiszerkereskedelmének szabályozása 2010 Budapest

http://elib.kkf.hu/edip/D 15115.pdf Letöltve: 2017.12.10

34. Forrai László: A túlélés alapjai mérsékelt égövi viszonyok között, Hadtudományi Szemle 2017. 10évfolyam 2. szám

35. Feller Adrienne, Tóbai Ágota: Aroma reneszánsz, Bookline Kiadó 2013

36. Balinkó S., Balinkó L., Kravolanszky: A szója feldolgozása, felhasználása, Mezőgazda Kiadó 2007

37. Algavirágzások környezetterhelése és toxinjainak variabilitása, Vasas Gábor Debreceni Egyetem 2014 PhD. Mezőgazda Kiadó2007

38.//balaicza.hu/az-elelmiszerek-es-adalekanyagokhisztamintartalma/ Letöltés: 2017.12.03.

39. A dividend in food safety, 1991 Public Safety NASA spinoff Database/

https://ntrs.nasa.gov/archive/nasa/casi.ntrs.nasa.gov/20020086314.pdf Letöltés: 2017.12.03.

40. Az élelmiszer-biztonság jelentősége a katonák kiszolgálásában, az állomány elégedettségének elérésében, élelmezési kultúrájának fejlesztésében, Katonai Logisztika 2007. 15 évfolyam 2 szám

41. http://portal.nebih.gov.hu/-/elelmiszer-jogszabalyok-jegyzeke Letöltés: 2017.12.04

42. Dr. Gál István, Dr. Bodnár Károly, Dr. Benkő-Kiss Árpád, Dr. Mikóné Jónás Edit, Dr. Majzinger István, Dr. Kocsisné dr. Gráff Myrtill, Dr. Barta Tamás, Dr. Bodnárné Dr. Skobrák Erika, Dr. Pinnyei Szilárd, Süli Ágnes, Benk Ákos: Állattenyésztési technológiák élelmiszer-biztonsági kérdései 2013

43. www.elbs.hu Élelmiszer-biztonsági Stratégia 2013-2022, Kiadó Nemzeti Élelmiszerlánc- biztonsági Hivatal Készítette: VM és NÉBIH Letöltés: 2017.12.01 
Katonai Logisztika 2018. évi 1-2. szám

44. https://ec.europa.eu/food/safety/food-fraud/ffn en Letöltés:2017.11.24

45. http://portal.nebih.gov.hu/hu/informaciok/elelmiszer/lakossagi Letöltés: 2017.12.01 